\title{
PELLETIZED PONDEROSA PINE BARK FOR ADSORPTION OF TOXIC HEAVY METALS FROM WATER
}

\author{
Miyoung Oh and Mandla A. Tshabalala*
}

Bark flour from ponderosa pine (Pinus ponderosa) was consolidated into pellets using citric acid as cross-linking agent. The pellets were evaluated for removal of toxic heavy metals from synthetic aqueous solutions. When soaked in water, pellets did not leach tannins, and they showed high adsorption capacity for $\mathrm{Cu}(\mathrm{II}), \mathrm{Zn}(\mathrm{II}), \mathrm{Cd}(\mathrm{II})$, and $\mathrm{Ni}(\mathrm{II})$ under both equilibrium and dynamic adsorption conditions. The experimental data for $\mathrm{Cd}$ (II) and $\mathrm{Zn}$ (II) showed a better fit to the Langmuir than to the Freundlich isotherm. The $\mathrm{Cu}$ (II) data best fit the Freundlich isotherm, and the $\mathrm{Ni}(\mathrm{II})$ data fitted both Freundlich and Langmuir isotherms equally. According to the Freundlich constant $K_{\mathrm{F}}$, adsorption capacity of pelletized bark for the metal ions in aqueous solution, $\mathrm{pH} 5.1 \pm 0.2$, followed the order $\mathrm{Cd}(\mathrm{II})>\mathrm{Cu}(\mathrm{II})>\mathrm{Zn}(\mathrm{II})>>\mathrm{Ni}(\mathrm{II})$; according to the Langmuir constant $b$, adsorption affinity followed the order $\mathrm{Cd}(\mathrm{II})>>\mathrm{Cu}(\mathrm{II}) \approx \mathrm{Zn}(\mathrm{II})>>\mathrm{Ni}(\mathrm{II})$. Although data from dynamic column adsorption experiments did not show a good fit to the Thomas kinetic adsorption model, estimates of sorption affinity series of the metal ions on pelletized bark derived from this model were not consistent with the series derived from the Langmuir or Freundlich isotherms and followed the order $\mathrm{Cu}(\mathrm{II})>\mathrm{Zn}(\mathrm{II}) \approx \mathrm{Cd}(\mathrm{II})>$ $\mathrm{Ni}(\mathrm{II})$. According to the Thomas kinetic model, the theoretical maximum amounts of metal that can be sorbed on the pelletized bark in a column at influent concentration of $\approx 10 \mathrm{mg} / \mathrm{L}$ and flow rate $=5 \mathrm{~mL} / \mathrm{min}$ were estimated to be $57,53,50$, and $27 \mathrm{mg} / \mathrm{g}$ for copper, zinc, cadmium, and nickel, respectively. This study demonstrated the potential for converting low-cost bark residues to value-added sorbents using starting materials and chemicals derived from renewable resources. These sorbents can be applied in the removal of toxic heavy metals from waste streams with heavy metal ion concentrations of up to $100 \mathrm{mg} / \mathrm{L}$ in the case of $\mathrm{Cu}(\mathrm{II})$.

Keywords: Bark, Sorbent, Adsorption, Metals, Pine, Nickel, Cadmium

Contact information: USDA Forest Service, Forest Products Laboratory, One Gifford Pinchot Drive, Madison, Wisconsin 53726-2398*Corresponding author: $\underline{\text { mtshabalala@fs.fed.us }}$

\section{INTRODUCTION}

Large amounts of bark residues are generated annually by primary timber processing mills worldwide. In the United States alone, an estimated 2.2 million metric tons of bark residues were generated in 2002 (McKeever and Falk 2004). In Canada, approximately 1,200 tons of residual bark was generated daily by Quebec mills (Frigon et al. 2003). Bark residues are therefore one of the most abundant renewable resources that are available for conversion into high-value, environmentally sustainable biomaterials, including low-cost sorbents for treatment of water streams contaminated with persistent organic pollutants (Brás et al. 1999, 2004; Ratola et al. 2003), toxic oily wastes (Haussard 
et al. 2003) and reactive dyes (Morais et al. 1999). Several investigators have also shown that bark from various species adsorbs toxic heavy metals from water to different extents (Randall 1977; Deshkar et al. 1990; Reddy et al. 1997; Seki et al. 1997; Gaballah and Kilbertus 1998; Villaescusa et al. 2000; Aoyama and Tsuda 2001; Martin-Dupont et al. 2002, 2004, 2006; Sekar et al. 2004).

In a review of potentially low-cost sorbents for heavy metals, Bailey et al, (1999) concluded that inexpensive, effective, readily available materials such as bark can be used in place of activated carbon or ion exchange resins for removal of heavy metals from solution, although cost comparisons of sorbents are difficult to make due to the scarcity of consistent cost information.

Concentrations of heavy metals in polluted streams vary, depending upon the type of heavy metal, source of pollution, stream location, and time of day. For example Van Hassel et al., (1980) found that heavy metal concentrations in stream water samples collected at three sites adjacent to highways were $2-6 \mu \mathrm{g} / \mathrm{L}$ for $\mathrm{Pb} ; 8-43 \mu \mathrm{g} / \mathrm{L}$ for $\mathrm{Zn}$; 1 $7 \mu \mathrm{g} / \mathrm{L}$ for $\mathrm{Ni}$; and $0.1-1.1 \mu \mathrm{g} / \mathrm{L}$ for $\mathrm{Cd}$. In a study on the assessment of heavy metal pollution at two South African harbors, Fatoki and Mathabatha, (2001) found that at one of the harbors, heavy metal concentrations in sea water receiving industrial discharges and urban stormwater runoff ranged from $0.2-72 \mathrm{mg} / \mathrm{L}$ for $\mathrm{Cd} ; 0.6-42.6 \mathrm{mg} / \mathrm{L}$ for $\mathrm{Cu}$; 0.6$16.3 \mathrm{mg} / \mathrm{L}$ for $\mathrm{Pb}$; and $0.5-27.6 \mathrm{mg} / \mathrm{L}$ for $\mathrm{Zn}$.

Bark flour is effective for removal of toxic heavy metal ions from water because of its high content of polyhydroxy polyphenolic groups that are capable of chelating heavy metal ions (Gaballah, I., and Kilbertus, G., 1998). In addition, bark contains carboxylic groups, which can bind metals by ion-exchange mechanisms (Sakai, K., 2001). However, because bark also contains significant quantities of water-soluble extractives, including soluble tannins, which can be detrimental to aquatic life, the bark needs to be treated before it is used as a sorbent material for removal of contaminants from water. To avoid release of soluble tannins from the bark into the water, Haussard et al. (2003) treated the bark with microorganisms or with copper or chromium solution and Vázquez et al. (2002) used acidified formaldehyde. Earlier studies by Chow (1972) had indicated that water soluble phenolic substances in bark can be condensed into waterinsoluble polymers by high-temperature heating. The objective of our study was to investigate whether or to what extent bark powder consolidated into pellets, using citric acid as cross linking agent and subjected to high-temperature heat treatment absorbs toxic heavy metals from water, under both static and dynamic flow conditions, without contributing to high chemical oxygen demand (COD) .

\section{MATERIALS AND METHODS}

Air-dried ponderosa pine (Pinus ponderosa) bark, obtained from a mill in St. Regis, Montana, U.S.A., was hammer milled into flour that passed through a 20-mesh screen. The flour was consolidated into pellets as described below.

Anhydrous citric acid was purchased from GFS Chemicals (Ohio, U.S.A.) and carboxymethylcellulose (CMC) was purchased from Hercules (Wisconsin, U.S.A.). Standard solutions of $\mathrm{Cu}$ (II), Ni (II), Zn (II), and Cd (II) were purchased from Fischer 
Scientific (New Jersey, U.S.A.) and diluted with deionized water to the appropriate concentration, as needed. Metal concentration in solution was determined by inductively coupled plasma atomic emission spectroscopy (ICP-AES).

\section{Preparation of Pelletized Bark}

Bark flour was mixed with CMC, citric acid, and deionized (DI) water in the proportions shown in Table 1. The ingredients were mixed thoroughly to form a stiff paste. CMC was used as a rheology modifier for pellet extrusion (Kulicke, W-M., et al., 1996). Citric acid was used as crosslinking agent to enhance the wet strength or watersoak properties and dimensional stability of the pellets (Caulfield, 1994). The stiff paste was extruded into cylindrical pellets, which were conditioned for $1 \mathrm{~h}$ at $180^{\circ} \mathrm{C}$ in a forced-draft furnace. The pelletized bark is shown in Figure 1. Type I pellets were selected for further studies because these pellets showed optimal wet strength and hydraulic conductivity in preliminary column experiments, and could be regenerated several times without measurable loss of weight and sorption capacity.

\section{Characteristics of Pelletized Bark}

A random sample of 10 pellets was taken for measurement of pellet size and breaking weight. Pellet size was measured by means of an electronic digital caliper, and breaking weight was measured on an Instron testing machine. Breaking weight is defined as the maximum compression load on the pellet just prior to failure.

The liquid-accessible pore volume of the pellets was measured according to the method described by DesMarais et al., (1993). For that purpose, 1.0-g samples of the pellets, weighed accurately to four decimal places, were immersed in DI water at $26.5 \pm$ $0.2^{\circ} \mathrm{C}$ for $8 \mathrm{~h}$. At the end of this period, the pellets were removed from the water, dabbed lightly with a piece of absorbent tissue paper to remove excess water from the surface, and weighed. Liquid-accessible pore volume $V_{\text {acc }}$ was calculated as

$$
V_{\text {acc }}=\left(W_{\text {wet }}-W_{\text {dry }}\right) d_{\text {water }}
$$

where $W_{\text {wet }}$ is weight (g) of the sample after saturation with DI water, $W_{\text {dry }}$ is initial weight of the sample at $30 \% \mathrm{RH}, 27 \pm 1^{\circ} \mathrm{C}$, and $d_{\text {water }}$ is density $\left(\mathrm{g} / \mathrm{cm}^{3}\right)$ of DI water at $26.5^{\circ} \mathrm{C}$. Characteristics of the pelletized bark are summarized in Table 2 .

Leaching characteristics of the pelletized bark were determined by comparing the chemical oxygen demand and UV-visible spectrum of $40 \mathrm{~mL}$ DI water before and after equilibration at room temperature $\left(25 \pm 1^{\circ} \mathrm{C}\right)$ for $2 \mathrm{~h}$ with $1 \mathrm{~g}$ pelletized bark. COD of DI water before and after equilibration were $0.55 \pm 0.47$ and $6.2 \pm 3.0 \mathrm{mg} / \mathrm{L}$, respectively.

Table 1. Weight of pellet ingredients

\begin{tabular}{|c|c|c|c|c|}
\hline Type $\begin{array}{c}\text { Type } \\
\text { of } \\
\text { pellet }\end{array}$ & \multicolumn{4}{|c|}{ Weight of ingredient (g) } \\
\cline { 2 - 5 } I & CMC & $\begin{array}{c}\text { Citric } \\
\text { acid }\end{array}$ & DI water \\
\hline II & 200 & 0.5 & 40 & 140 \\
\hline III & 200 & 0.14 & 20 & 74 \\
\hline
\end{tabular}




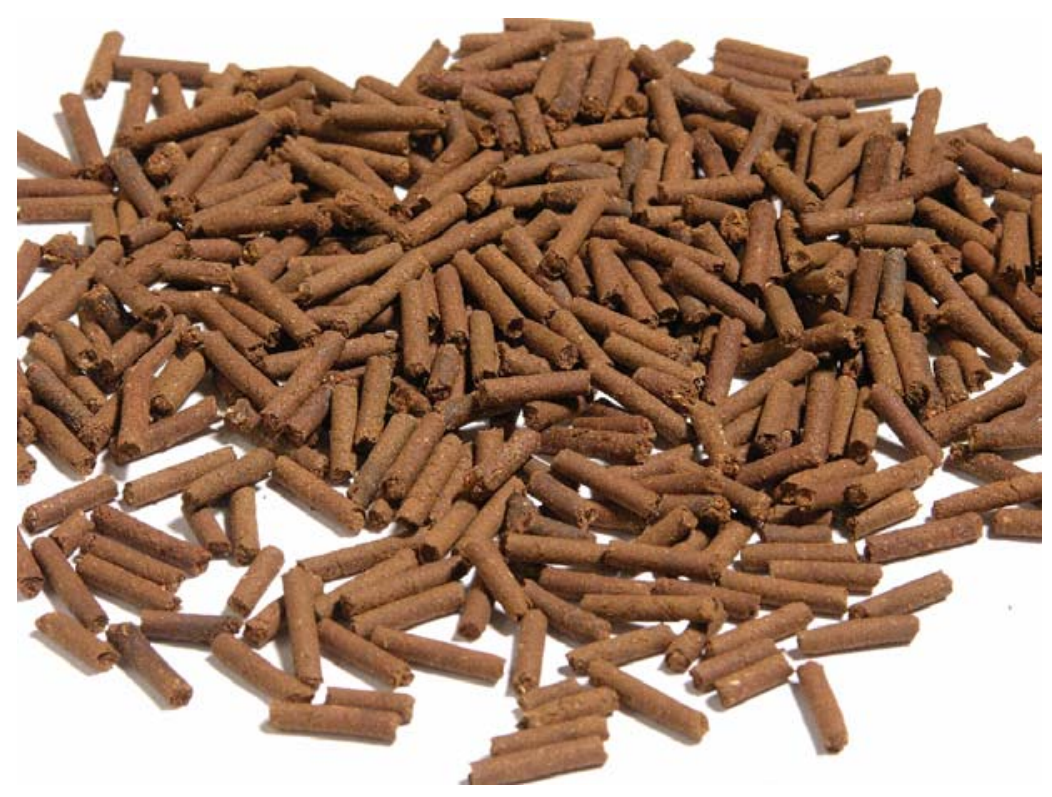

Fig. 1. Pelletized bark (Type I).

Because the DI water before and after equilibration with the bark pellets did not show the UV-visible absorbance band with $\lambda_{\max }=280 \mathrm{~nm}$, which is characteristic of tannins, it can

\begin{tabular}{|l|c|}
\hline Table 2. Characteristics of Pelletized Bark-Type I \\
\hline Parameter & Value \\
\hline Shape & Cylindrical \\
\hline Length, $\mathrm{mm}$ & $11.60 \pm 2.11$ \\
\hline Diameter, $\mathrm{mm}$ & $3.28 \pm 0.16$ \\
\hline Breaking weight, $\mathrm{kg} / \mathrm{pellet}$ & $6.15 \pm 2.0$ \\
\hline Shipping weight, $\mathrm{g} / \mathrm{L}$ & 310 \\
\hline Liquid-accessible pore volume, $\mathrm{cm}^{3} / \mathrm{g}$ & $0.8-1.0$ \\
\hline
\end{tabular}

be concluded that no tannin leached from the bark pellets. The slight increase in COD may have been from soluble carbohydrates leaching from the pellets.

\section{Equilibrium Adsorption Experiments}

Equilibrium adsorption experiments were performed in triplicate by adding 0.5-g aliquots of pelletized bark to labeled $125-\mathrm{mL}$ polyethylene bottles. $20-\mathrm{mL}$ aliquots of $\mathrm{Cu}(\mathrm{II}), \mathrm{Zn}(\mathrm{II}), \mathrm{Ni}(\mathrm{II})$, or $\mathrm{Cd}(\mathrm{II})$ solutions of various initial concentrations ( $C_{0}=0.1,0.5$, $1.0,2.0,5.0,10,50,100,200,500 \mathrm{mg} / \mathrm{L}), \mathrm{pH} 5.1 \pm 0.02$, were equilibrated at $25 \pm 1{ }^{\circ} \mathrm{C}$ with the pelletized bark by shaking the capped bottles for $24 \mathrm{~h}$ on a horizontal shaker at $150 \mathrm{rpm}$. Preliminary experiments had indicated that equilibrium could be reached within $2 \mathrm{~h}$. At the end of this period, equilibrium concentration $C_{\mathrm{e}}$ of the metal ion in the supernatant liquid was determined by ICP-AES (USEPA Method 6010B, 1996). 


\section{Adsorption Kinetics Experiments}

Adsorption kinetics experiments were performed in 1-L solutions with $1.0 \mathrm{~g}$ samples of the pelletized bark. The initial metal ion concentration in solution was 10 $\mathrm{mg} / \mathrm{L}$, and initial $\mathrm{pH}$ was 2,4 , or 6 . The initial $\mathrm{pH}$ of the solution was adjusted by adding $0.1 \mathrm{M} \mathrm{HNO}_{3}$ or $\mathrm{KOH}$ as needed. The suspension was stirred using a magnetic bar, and 1$\mathrm{mL}$ aliquots of the supernatant liquid were withdrawn for metal concentration determination by ICP-AES at various time intervals during the 2-h experiment.

\section{Dynamic Adsorption Experiments}

Dynamic adsorption experiments were conducted in a glass column, $25 \mathrm{~mm}$ in diameter and $400 \mathrm{~mm}$ in length. The column was packed with $40 \mathrm{~g}$ pelletized bark to a bed height of $300 \mathrm{~mm}$. Five column volumes of DI water were pumped through the column before each metal ion solution of a given initial concentration was pumped through the column at a flow rate of $5 \mathrm{~mL} / \mathrm{min}$. The initial metal ion concentration of the solutions was $C_{\mathrm{infl}}=1,10,25,50,70,100,250 \mathrm{mg} / \mathrm{L}$. The column effluent was collected in test tubes by means of a fraction collector, and the effluent metal ion concentration $C_{\text {effl }}$ was determined by ICP-AES.

\section{RESULTS AND DISCUSSION}

\section{Adsorption Isotherms}

The amount of metal ions adsorbed at equilibrium, $q_{\mathrm{e}}(\mathrm{mg} / \mathrm{g})$, was calculated as

$$
q_{\mathrm{e}}=\left(C_{0}-C_{\mathrm{e}}\right) V / W
$$

where $C_{0}$ and $C_{\mathrm{e}}$ are concentrations $(\mathrm{mg} / \mathrm{L})$ of metal ions in the initial and equilibrium solutions, respectively, $V$ is volume (L) of the initial solution taken for equilibration, and $W(\mathrm{~g})$ is the weight of the pellets taken for equilibration.

Experimental results obtained for adsorption of metal ions at equilibrium were analyzed by both the Freundlich and Langmuir adsorption isotherms. The Freundlich isotherm is described by

$$
q_{\mathrm{e}}=K_{\mathrm{F}} C_{\mathrm{e}}^{1 / n}
$$

where $K_{\mathrm{F}}$ is a constant related to the adsorption capacity and $n$ is an empirical parameter related to the intensity of adsorption, which varies with the heterogeneity of the adsorbent. Adsorption is favorable for values $0.1<1 / n<1$ (Namasivayam and Yamuna 1992; Raji and Anirudhan 1998). The Langmuir isotherm is described by

$$
q_{\mathrm{e}}=q_{\max } b C_{\mathrm{e}} /\left(1+b C_{\mathrm{e}}\right)
$$

where $q_{\max }$ is the maximum amount of adsorbate per unit weight of adsorbent and $b$ is a parameter related to the free energy of adsorption of a monolayer of the adsorbate. It 
reflects the adsorption intensity and characterizes the affinity of the adsorbent for the adsorbate.

Fig. 2 shows Freundlich and Langmuir adsorption isotherms for $\mathrm{Cu}(\mathrm{II}), \mathrm{Zn}(\mathrm{II})$, $\mathrm{Ni}(\mathrm{II})$, and $\mathrm{Cd}(\mathrm{II})$ ions on pelletized bark. Isotherm parameters for adsorption of each of the metal ions on pelletized bark are summarized in Table 3. As shown by the values of the root mean squared errors of the nonlinear least squares fit (RMSE), the experimental data for $\mathrm{Cd}(\mathrm{II})$ and $\mathrm{Zn}$ (II) showed a better fit to the Langmuir than to the Freundlich isotherm. The $\mathrm{Cu}(\mathrm{II})$ data best fit the Freundlich isotherm, and the $\mathrm{Ni}$ (II) data fitted both Freundlich and Langmuir isotherms equally. According to the Freundlich constant $K_{\mathrm{F}}$, adsorption capacity of pelletized bark for the metal ions in aqueous solution, $\mathrm{pH} 5.1 \pm$ 0.2 , followed the order $\mathrm{Cd}(\mathrm{II})>\mathrm{Cu}(\mathrm{II})>\mathrm{Zn}(\mathrm{II})>>\mathrm{Ni}(\mathrm{II})$; according the Langmuir constant $b$, adsorption affinity followed the order $\mathrm{Cd}(\mathrm{II})>>\mathrm{Cu}(\mathrm{II}) \approx \mathrm{Zn}$ (II) $>>\mathrm{Ni}$ (II).

Table 3. Freundlich and Langmuir isotherm parameters for metal ion adsorption on pelletized bark, $\mathrm{pH} 5.1 \pm 0.2$

\begin{tabular}{|c|c|c|c|c|c|c|c|c|}
\hline & \multicolumn{3}{|c|}{ Freundlich isotherm } & \multicolumn{3}{c|}{ Langmuir isotherm } \\
\cline { 2 - 9 } Ion & $K_{\mathrm{F}}$ & $1 / n$ & $R$ & RMSE & $\begin{array}{c}q_{\max } \\
(\mathrm{mg} / \mathrm{g})\end{array}$ & $b$ & $R$ & RMSE \\
\hline $\mathrm{Cu}(\mathrm{II})$ & 84.6 & 0.79 & 0.9993 & 102 & 24.1 & 0.0016 & 0.9982 & 171 \\
\hline $\mathrm{Zn}(\mathrm{II})$ & 73.7 & 0.80 & 0.9960 & 238 & 20.6 & 0.0018 & 0.9971 & 200 \\
\hline $\mathrm{Ni}(\mathrm{II})$ & 19.8 & 0.88 & 0.9964 & 117 & 20.6 & 0.0006 & 0.9964 & 120 \\
\hline $\mathrm{Cd}(\mathrm{II})$ & 203 & 0.54 & 0.9947 & 200 & 6.8 & 0.0069 & 0.9998 & 41 \\
\hline
\end{tabular}

$R$ is correlation coefficient.

RMSE is root mean squared error of nonlinear least squares fit.

Table 4. Pseudo-first- and second-order kinetic parameters for $\mathrm{Cu}(\mathrm{II})$ sorption

\begin{tabular}{|c|c|c|c|c|c|l|l|c|}
\hline & \multicolumn{4}{|c|}{ Pseudo-first order } & \multicolumn{4}{c|}{ Pseudo-second order } \\
\cline { 2 - 9 } $\mathrm{pH}$ & $\begin{array}{c}q_{\mathrm{e}} \\
(\mathrm{mg} / \mathrm{g})\end{array}$ & $\begin{array}{c}k_{1} \\
\left(\mathrm{~min}^{-1}\right)\end{array}$ & $R$ & RMSE & $q_{\mathrm{e}}(\mathrm{mg} / \mathrm{g})$ & $\begin{array}{c}k_{2} \\
(\mathrm{~g} / \mathrm{mg} / \mathrm{min})\end{array}$ & $R$ & RMSE \\
\hline 2 & $\begin{array}{c}0.728 \\
\pm 0.021\end{array}$ & $\begin{array}{l}0.0641 \\
\pm 0.000\end{array}$ & 0.9835 & 0.0496 & $\begin{array}{l}0.786 \\
\pm 0.022\end{array}$ & $\begin{array}{l}0.114 \\
\pm 0.003\end{array}$ & 0.9592 & 0.0788 \\
\hline 4 & $\begin{array}{c}0.669 \\
\pm 0.030\end{array}$ & $\begin{array}{c}0.0882 \\
\pm 0.004\end{array}$ & 0.9955 & 0.0250 & $\begin{array}{l}0.731 \\
\pm 0.027\end{array}$ & $\begin{array}{l}0.170 \\
\pm 0.008\end{array}$ & 0.9770 & 0.0558 \\
\hline 6 & $\begin{array}{c}0.524 \\
\pm 0.004\end{array}$ & $\begin{array}{l}0.0532 \\
\pm 0.006\end{array}$ & 0.9948 & 0.0200 & $\begin{array}{l}0.567 \\
\pm 0.002\end{array}$ & $\begin{array}{l}0.128 \\
\pm 0.017\end{array}$ & 0.9872 & 0.0313 \\
\hline
\end{tabular}

Table 5. Pseudo-first- and second-order kinetic parameters for $\mathrm{Zn}(\mathrm{II})$ sorption

\begin{tabular}{|c|c|c|c|c|c|c|c|c|}
\hline & \multicolumn{4}{|c|}{ Pseudo-first order } & \multicolumn{3}{c|}{ Pseudo-second order } \\
\cline { 2 - 9 } & $\begin{array}{c}q_{\mathrm{e}} \\
(\mathrm{mg} / \mathrm{g})\end{array}$ & $\begin{array}{c}k_{1} \\
\left(\mathrm{~min}^{-1}\right)\end{array}$ & $R$ & RMSE & $q_{\mathrm{e}}(\mathrm{mg} / \mathrm{g})$ & $\begin{array}{c}k_{2} \\
(\mathrm{~g} / \mathrm{mg} / \mathrm{min})\end{array}$ & $R$ & RMSE \\
\hline 2 & $\begin{array}{c}0.646 \\
\pm 0.011\end{array}$ & $\begin{array}{c}0.0348 \\
\pm 0.000\end{array}$ & 0.9910 & 0.0319 & $\begin{array}{l}0.696 \\
\pm 0.013\end{array}$ & $\begin{array}{l}0.0645 \\
\pm 0.000\end{array}$ & 0.9884 & 0.0366 \\
\hline 4 & $\begin{array}{c}0.406 \\
\pm 0.015\end{array}$ & $\begin{array}{c}0.0514 \\
\pm 0.000\end{array}$ & 0.9676 & 0.0403 & $\begin{array}{l}0.437 \\
\pm 0.016\end{array}$ & $\begin{array}{l}0.158 \\
\pm 0.006\end{array}$ & 0.9316 & 0.0580 \\
\hline 6 & $\begin{array}{c}0.438 \\
\pm 0.030\end{array}$ & $\begin{array}{c}0.0502 \\
\pm 0.001\end{array}$ & 0.9960 & 0.0150 & $\begin{array}{l}0.473 \\
\pm 0.034\end{array}$ & $\begin{array}{l}0.146 \\
\pm 0.019\end{array}$ & 0.9834 & 0.0296 \\
\hline
\end{tabular}


Freundlich isotherms
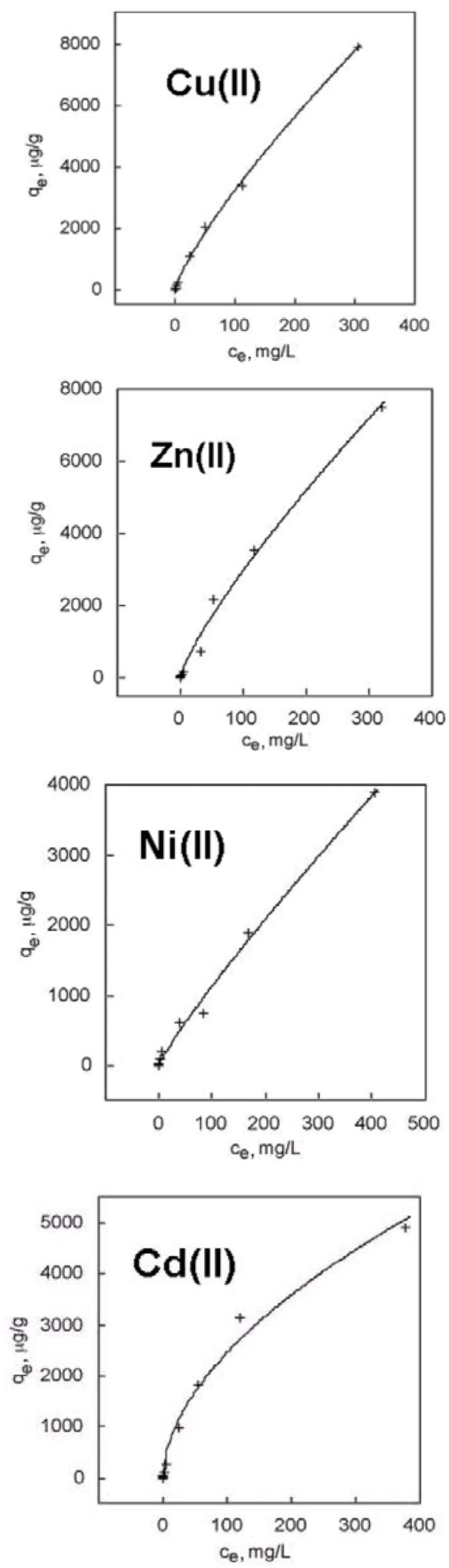

Langmuir isotherms
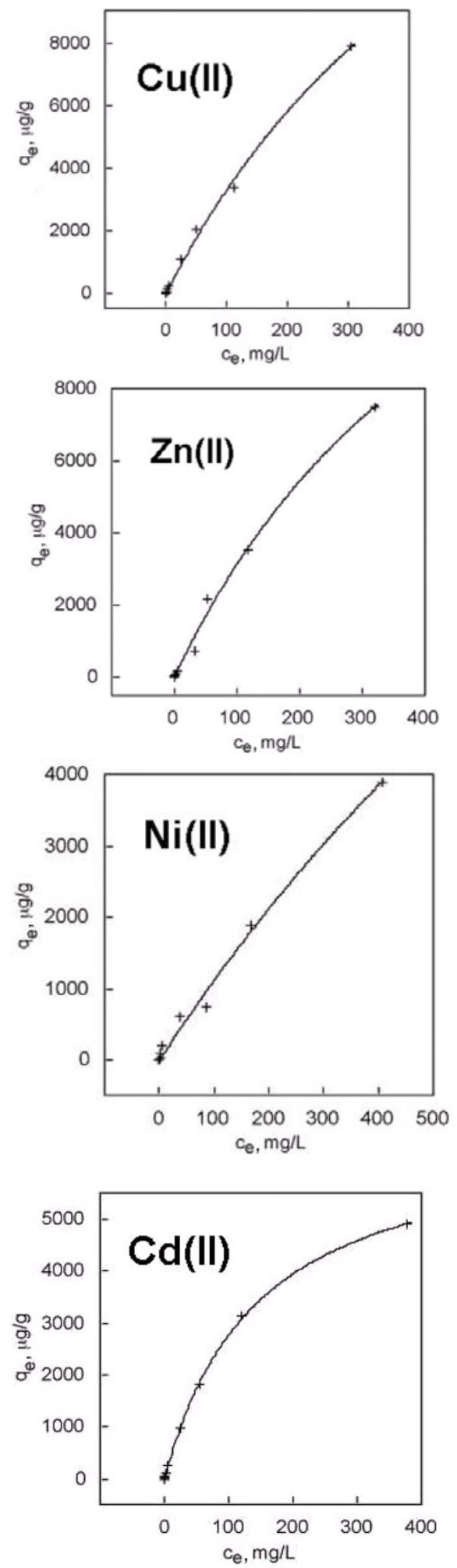

Fig. 2. Freundlich and Langmuir adsorption isotherms for $\mathrm{Cu}(\mathrm{II}), \mathrm{Zn}(\mathrm{II}), \mathrm{Ni}(\mathrm{II})$, and $\mathrm{Cd}(\mathrm{II})$ ions on pelletized bark. [Note: markers $(+)$ represent experimental data points, and the lines (-----) represent the fitted isotherms] 


\section{Adsorption Kinetics}

Experimental data were analyzed by both pseudo-first- and second-order kinetic models, as described in the following equations, respectively (Ho and McKay 1999):

$$
\begin{gathered}
q_{\mathrm{t}}=q_{\mathrm{e}}\left[1-\exp \left(-k_{1} t\right)\right]+\varepsilon \\
q_{\mathrm{t}}=q_{\mathrm{e}}-1 /\left[\left(1 / q_{\mathrm{e}}\right)+k_{2} t\right]+\varepsilon
\end{gathered}
$$

where $k_{1}$ is the rate constant of the pseudo-first-order model $(1 / \mathrm{min}), k_{2}$ is the rate constant of the pseudo-second-order model $(\mathrm{g} / \mathrm{mg} / \mathrm{min}), q_{\mathrm{e}}$ is the amount of solute adsorbed at equilibrium $(\mathrm{mg} / \mathrm{g}), q_{t}$ is the amount of solute adsorbed on the surface of the sorbent at any time $t(\mathrm{mg} / \mathrm{g})$, and $\varepsilon$ denotes random error.

The kinetic parameters for metal ion sorption on pelletized bark determined by fitting the experimental data to both pseudo-first- and second-order kinetic models are summarized in Tables 4-7. As shown by the values of RMSE, sorption of metal ions on pelletized bark, except for $\mathrm{Cd}(\mathrm{II})$, best fit the pseudo-first-order kinetic model under all three $\mathrm{pH}$ conditions, 2, 4 and 6. $\mathrm{Cd}(\mathrm{II})$ deviated from this trend at $\mathrm{pH} 4$, where it best fit the pseudo-second-order kinetic model.

Adsorption kinetics of a given metal ion on pelletized bark are determined by its characteristic solution chemistry and by the surface chemistry of the pelletized bark. Specifically, solution $\mathrm{pH}$ plays an important role in determining both the nature of metal ionic species available in aqueous solution and the nature and concentration of adsorption sites on the bark pellet. Bark pellets have a high content of polyhydroxyl polyphenolic groups that are capable of chelating heavy metal ions. In addition, bark pellets contain carboxylic groups that can bind metals by ion-exchange mechanisms (Vázquez et al., 2002; Martin-Dupont et al 2006). Availability of ion-exchange groups is strongly influenced by $\mathrm{pH}$. Thus at low $\mathrm{pH}$ values, carboxylic groups should be predominantly non-ionized, and therefore unavailable for ion-exchange with a metal ion. However as $\mathrm{pH}$ increases, more and more carboxylic groups will be ionized and become available for ion-exchange with a metal ion. On the contrary, the distribution of hydrolysis species of metal ions as a function of $\mathrm{pH}$ is different for each metal ion. Thus, each metal ion will show its own characteristic adsorption kinetics depending on the distribution of its hydrolysis products at a given solution $\mathrm{pH}$.

\section{Cu(II) adsorption kinetics}

The speciation diagram for $\mathrm{Cu}(\mathrm{II})$ indicates that in the $\mathrm{pH}$ range $2-4.9, \mathrm{Cu}(\mathrm{II})$ ions in aqueous solution may exist in two forms: $\mathrm{Cu}(\mathrm{aq})^{2+}$ and $\mathrm{Cu}\left(\mathrm{NO}_{3}\right)^{+}$. In the $\mathrm{pH}$ range 5.06.0 an additional two species may appear: $\mathrm{Cu}(\mathrm{OH})^{+}$and $\mathrm{Cu}(\mathrm{OH})_{\text {aq }}$ (Vuceta and Morgan 1977). Thus, adsorption kinetics of $\mathrm{Cu}(\mathrm{II})$ ions will be limited by the rate of adsorption of the dominant species at a given solution $\mathrm{pH}$. As shown in Table 4, $q_{\mathrm{e}}$ values for $\mathrm{Cu}$ (II) sorption predicted by both kinetic models decreased with increase in $\mathrm{pH}$. However both pseudo-first-order $\left(k_{1}\right)$ and pseudo-second-order $\left(k_{2}\right)$ rate constants showed a maximum at $\mathrm{pH}$ 4. This suggests that the rate of $\mathrm{Cu}(\mathrm{II})$ sorption is determined by $\mathrm{Cu}(\mathrm{aq})^{2+}$ ion concentration, and as this concentration decreases at $\mathrm{pH}$ greater than 4 , the rate of $\mathrm{Cu}(\mathrm{II})$ sorption decreases accordingly because of formation of other $\mathrm{Cu}$ (II) species, such as 
Table 6. Pseudo-first- and second-order kinetic parameters for $\mathrm{Cd}(\mathrm{II})$ sorption

\begin{tabular}{|c|c|c|c|c|c|c|c|c|}
\hline & \multicolumn{3}{|c|}{ Pseudo-first order } & \multicolumn{4}{c|}{ Pseudo-second order } \\
\cline { 2 - 9 } $\mathrm{pH}$ & $\begin{array}{c}q_{\mathrm{e}} \\
(\mathrm{mg} / \mathrm{g})\end{array}$ & $\begin{array}{c}k_{1} \\
\left(\mathrm{~min}^{-1}\right)\end{array}$ & $R$ & RMSE & $q_{\mathrm{e}}(\mathrm{mg} / \mathrm{g})$ & $\begin{array}{c}k_{2} \\
(\mathrm{~g} / \mathrm{mg} / \mathrm{min})\end{array}$ & $R$ & RMSE \\
\hline 2 & $\begin{array}{c}0.463 \\
\pm 0.032\end{array}$ & $\begin{array}{c}0.1158 \\
\pm 0.004\end{array}$ & 0.9926 & 0.0204 & $\begin{array}{l}0.502 \\
\pm 0.036\end{array}$ & $\begin{array}{l}0.356 \\
\pm 0.042\end{array}$ & 0.9740 & 0.0378 \\
\hline 4 & $\begin{array}{c}0.398 \\
\pm 0.029\end{array}$ & $\begin{array}{c}0.0730 \\
\pm 0.030\end{array}$ & 0.9798 & 0.0333 & $\begin{array}{l}0.458 \\
\pm 0.044\end{array}$ & $\begin{array}{l}0.207 \\
\pm 0.117\end{array}$ & 0.9877 & 0.0240 \\
\hline 6 & $\begin{array}{l}0.414 \\
\pm 0.037\end{array}$ & $\begin{array}{c}0.0816 \\
\pm 0.010\end{array}$ & 0.9928 & 0.0184 & $\begin{array}{l}0.447 \\
\pm 0.040\end{array}$ & $\begin{array}{l}0.272 \\
\pm 0.020\end{array}$ & 0.9798 & 0.0292 \\
\hline
\end{tabular}

Table 7. Pseudo-first- and second-order kinetic parameters for Ni(II) sorption

\begin{tabular}{|c|c|c|c|c|c|c|c|c|}
\hline & \multicolumn{4}{|c|}{ Pseudo-first order } & \multicolumn{3}{c|}{ Pseudo-second order } \\
\cline { 2 - 9 } $\mathrm{pH}$ & $\begin{array}{c}q_{\mathrm{e}} \\
(\mathrm{mg} / \mathrm{g})\end{array}$ & $\begin{array}{c}k_{1} \\
\left(\mathrm{~min}^{-1}\right)\end{array}$ & $R$ & RMSE & $\begin{array}{c}q_{\mathrm{e}} \\
(\mathrm{mg} / \mathrm{g})\end{array}$ & $\begin{array}{c}k_{2} \\
(\mathrm{~g} / \mathrm{mg} / \mathrm{min})\end{array}$ & $R$ & RMSE \\
\hline 2 & $\begin{array}{c}0.434 \\
\pm 0.014\end{array}$ & $\begin{array}{c}0.0765 \\
\pm 0.012\end{array}$ & 0.9938 & 0.0185 & $\begin{array}{l}0.471 \\
\pm 0.016\end{array}$ & $\begin{array}{l}0.235 \\
\pm 0.054\end{array}$ & 0.9786 & 0.0311 \\
\hline 4 & $\begin{array}{l}0.376 \\
\pm 0.004\end{array}$ & $\begin{array}{l}0.0509 \\
\pm 0.003\end{array}$ & 0.9960 & 0.0127 & $\begin{array}{l}0.408 \\
\pm 0.005\end{array}$ & $\begin{array}{l}0.167 \\
\pm 0.008\end{array}$ & 0.9884 & 0.0206 \\
\hline 6 & $\begin{array}{l}0.257 \\
\pm 0.018\end{array}$ & $\begin{array}{c}0.0791 \\
\pm 0.022\end{array}$ & 0.9813 & 0.0173 & $\begin{array}{l}0.280 \\
\pm 0.018\end{array}$ & $\begin{array}{l}0.408 \\
\pm 0.117\end{array}$ & 0.9708 & 0.0215 \\
\hline
\end{tabular}

$\mathrm{Cu}(\mathrm{OH})_{\mathrm{aq}}$ in solution that are not adsorbed by ion-exchange reaction with $\mathrm{H}^{+}$ions on the bark pellets. Gaballah and Kilbertus, 1998 also reported a similar trend in $\mathrm{pH}$ dependence of $\mathrm{Cu}$ (II) adsorption on modified pine bark

\section{Zn(II) adsorption kinetics}

The speciation diagram for $\mathrm{Zn}(\mathrm{II})$ indicates that in the $\mathrm{pH}$ range $2-6.5, \mathrm{Zn}(\mathrm{II})$ ions in aqueous solution exist only in one form, $\mathrm{Zn}(\mathrm{aq})^{2+}$ (Zhang and Muhammed 2001). Thus, adsorption kinetics of $\mathrm{Zn}(\mathrm{II})$ ions should be independent of $\mathrm{pH}$ in the range 2-6. Indeed, as shown in Table 5, no relationship is apparent between solution $\mathrm{pH}$ values and $q_{\mathrm{e}}$ values or pseudo-first- and second-order rate constants ( $k_{1}$ and $k_{2}$, respectively) for $\mathrm{Zn}$ (II) sorption on bark pellets. This suggests that interaction of $\mathrm{Zn}$ (II) in the $\mathrm{pH}$ range 24 is not by ion-exchange with $\mathrm{H}^{+}$ions on the bark pellets, but rather involves other mechanisms, such as surface complexation or hydrogen-bonding between the hydrated $\mathrm{Zn}(\mathrm{aq})^{2+}$ ions and the bark polyhydroxyl-polyphenolic groups (Ravat et al., 2000; Reddy et al., 1997).

\section{Cd(II) adsorption kinetics}

Similar to $\mathrm{Zn}(\mathrm{II})$, at $\mathrm{pH}$ values below 7, $\mathrm{Cd}(\mathrm{II})$ exists in aqueous solution only as the $\mathrm{Cd}(\mathrm{aq})^{2+}$ species (Leyva-Ramos et al. 1997). Accordingly, its adsorption kinetics on bark pellets should also be similar to that of $\mathrm{Zn}$ (II). As shown in Table 6 there was no correlation between solution $\mathrm{pH}$ and $q_{\mathrm{e}}$ values or the rate constants $k_{1}$ or $k_{2}$ for $\mathrm{Cd}$ (II) sorption on bark pellets. Thus, a reasonable conclusion is that in the $\mathrm{pH}$ range 2-6, adsorption mechanism of $\mathrm{Cd}(\mathrm{II})$ is by surface complexation with polyphenolic groups in the bark. This is consistent with observations made by Ravat et al., (2000) that sorption of 
$\mathrm{Cd}(\mathrm{II}), \mathrm{Zn}(\mathrm{II})$ and $\mathrm{Ni}(\mathrm{II})$ on lignocellulosic substrates showed less dependence on $\mathrm{pH}$ than that of $\mathrm{Cu}(\mathrm{II})$.

Table 8. Some physical and chemical characteristics of metal ions ${ }^{a}$

\begin{tabular}{|c|c|c|c|}
\hline Ion & $\begin{array}{c}\text { Charge- } \\
\text { size } \\
\text { function, } \\
\mathrm{Z}^{2} / r\end{array}$ & $\begin{array}{c}\text { Hydration } \\
\text { enthalpy, } \\
\Delta H_{\mathrm{h}} \\
(\mathrm{kJ} / \mathrm{mol})\end{array}$ & $\begin{array}{c}\text { First } \\
\text { hydrolysis } \\
\text { constant, } \\
\mathrm{pK}_{\mathrm{pq}}\end{array}$ \\
\hline $\mathrm{Cu}^{2+}$ & 5.48 & $-2,100$ & 7.9 \\
\hline $\mathrm{Zn}^{2+}$ & 5.33 & $-1,807$ & 7.5 \\
\hline $\mathrm{Ni}^{2+}$ & 5.71 & $-2,105$ & 9.6 \\
\hline $\mathrm{Cd}^{2+}$ & 4.21 & $-2,046$ & 9.0 \\
\hline
\end{tabular}

${ }^{a}$ Huheey 1972; Ahmed et al. 1998; MartinDupont et al. 2002.

\section{Ni(II) adsorption kinetics}

Although at $\mathrm{pH}$ values below $7 \mathrm{Ni}$ (II) exists in aqueous solution only as the $\mathrm{Ni}(\mathrm{aq})^{2+}$ species (Ji and Cooper 1996), its adsorption kinetics on bark appeared to be similar to $\mathrm{Cu}(\mathrm{II})$ adsorption kinetics because the $q_{\mathrm{e}}$ values showed a decrease with increase in $\mathrm{pH}$ from 2 to 6 . However, unlike for $\mathrm{Cu}$ (II), rate constants $k_{1}$ and $k_{2}$ showed a minimum at $\mathrm{pH} 4$ (Table 7), which is difficult to explain. However, above $\mathrm{pH} 4$ the increase in the rate constant appears to be consistent with $\mathrm{H}^{+}$ion-exchange reaction mechanism.

Table 8 shows some physical and chemical characteristics of metal ions that may have a bearing on their respective rates of reaction with the ligands on the bark. As a first approximation, it can be argued that the ease with which each hydrated metal ion reacts with a ligand on the bark sorbent should be determined by how readily a molecule of water is displaced from its hydration shell. The hydration enthalpy $\Delta H_{\mathrm{h}}$ corresponds to the energy required to displace $\mathrm{H}_{2} \mathrm{O}$ molecules from cations, and therefore reflects how easily the cation reacts with a ligand located on the bark; the higher the hydration enthalpy, the more difficult for the cation to react with the ligand on the bark. For the cations under consideration in this study, hydration enthalpy follows the decreasing order: $\mathrm{Ni}(\mathrm{II})>\mathrm{Cu}(\mathrm{II})>\mathrm{Cd}(\mathrm{II})>\mathrm{Zn}(\mathrm{II})$, which should translate to the following decreasing order of theoretical affinity of the cations for the bark ligand: $\mathrm{Zn}$ (II) $>\mathrm{Cd}$ (II) $>\mathrm{Cu}(\mathrm{II})>\mathrm{Ni}$ (II). However this order of theoretical affinity is not in agreement with our experimental data. In the case of divalent cations, the first hydrolysis constant, $\mathrm{pK}_{\mathrm{pq}}$ represents the extent to which the cation is converted to a monovalent species, $\mathrm{M}(\mathrm{OH})^{+}$ by hydrolysis. For the cations under consideration in this study, the first hydrolysis constant follows the decreasing order: $\mathrm{Zn}(\mathrm{II})>\mathrm{Cu}(\mathrm{II})>\mathrm{Cd}(\mathrm{II})>\mathrm{Ni}$ (II), which is in better agreement with our experimental data. This supports the hypothesis that in addition to the effect of $\mathrm{pH}$ on the speciation of each metal ion, $\mathrm{pH}$ effect on the degree of ionization of the carboxyl (R-COOH), hydroxyl $(\mathrm{R}-\mathrm{OH})$ and phenolic $(\varphi-\mathrm{OH})$ ligands on the bark is equally important. Thus under a given set of solution conditions, such as $\mathrm{pH}$ and ionic strength, each metal ion species, depending on its respective physical and chemical 
characteristics, will react more readily with those ligands that are available under the given $\mathrm{pH}$ conditions.

\section{Dynamic Adsorption Experiments}

Breakthrough curves for $\mathrm{Cu}(\mathrm{II}), \mathrm{Zn}(\mathrm{II}), \mathrm{Ni}(\mathrm{II})$, and $\mathrm{Cd}(\mathrm{II})$ are shown in Figure 3. The breakthrough volume, defined as the volume of column effluent where the ratio of the effluent-to-influent concentration of a metal ion is equal to 0.5 , was estimated from a logarithmic curve fit of the experimental data. The regression equations and the value of breakthrough volumes, calculated from these equations for each of the ions, are summarized in Table 9. Breakthrough volumes decreased in the order $\mathrm{Cu}(\mathrm{II})>\mathrm{Zn}$ (II) $>$ $\mathrm{Cd}(\mathrm{II})>\mathrm{Ni}(\mathrm{II})$ at influent $\mathrm{pH} 5.1 \pm 0.2$.

To determine the amount of metal ion adsorbed per unit weight of pellets under flow through column conditions, the breakthrough data were fitted to the linearized form of Thomas equation (Kapoor and Viraraghavan 1998):

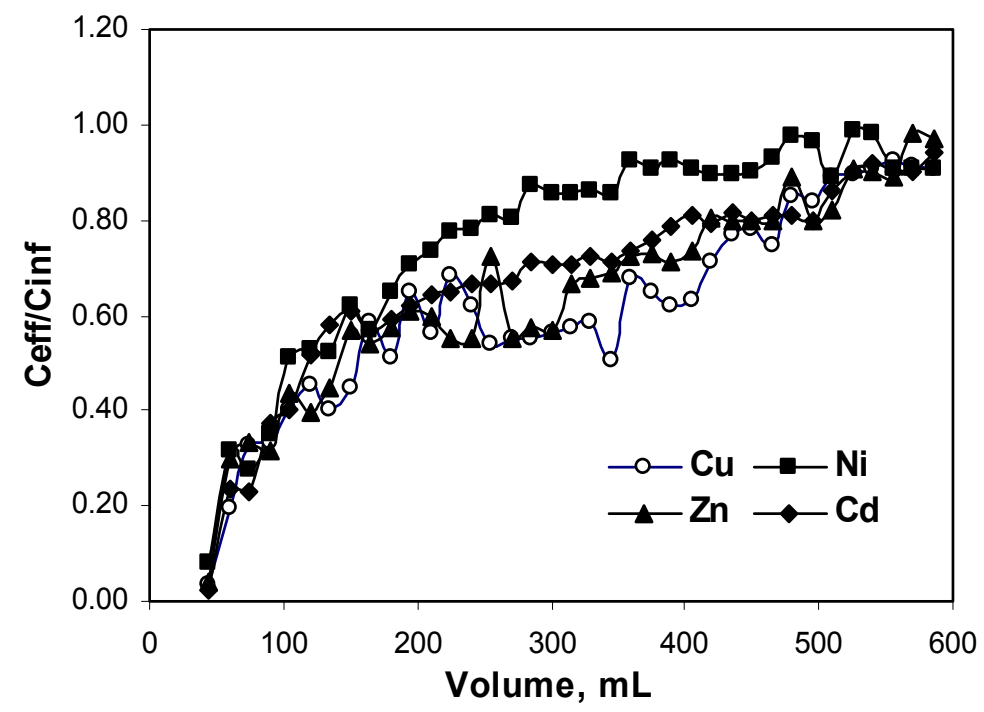

Fig. 3. Breakthrough curves for $\mathrm{Cu}(\mathrm{II}), \mathrm{Zn}(\mathrm{II}), \mathrm{Ni}(\mathrm{II})$, and $\mathrm{Cd}(\mathrm{II})$ at flow rate $5 \mathrm{~mL} / \mathrm{min}$, influent $\mathrm{pH} 5.1 \pm 0.2$, influent concentration $\approx 10.0 \mathrm{mg} / \mathrm{L}$.

Table 9. Calculated breakthrough volumes of $\mathrm{Cu}(\mathrm{II}), \mathrm{Zn}(\mathrm{II})$, $\mathrm{Ni}(\mathrm{II})$, and $\mathrm{Cd}(\mathrm{II})$ on pelletized bark at flow rate $5 \mathrm{~mL} / \mathrm{min}$, influent $\mathrm{pH} 5.1 \pm 0.2$, and influent concentration $\approx 10.0 \mathrm{mg} / \mathrm{L}$

\begin{tabular}{|c|c|c|c|}
\hline Metal ion & Regression equation & $R^{2}$ & $\begin{array}{l}\text { Breakthrough } \\
\text { volume, } \mathrm{mL}\end{array}$ \\
\hline $\mathrm{Cu}(\mathrm{II})$ & $y=0.2857 \operatorname{Ln}(x)-0.9758$ & 0.8628 & 175 \\
\hline $\mathrm{Zn}(\mathrm{II})$ & $y=0.2948 \operatorname{Ln}(x)-0.9949$ & 0.9198 & 159 \\
\hline $\mathrm{Ni}(\mathrm{II})$ & $y=0.3208 \operatorname{Ln}(x)-1.0263$ & 0.9542 & 116 \\
\hline $\mathrm{Cd}(\mathrm{II})$ & $y=0.2952 \operatorname{Ln}(x)-0.9702$ & 0.9419 & 146 \\
\hline
\end{tabular}




$$
\log \left(C_{\text {inf }} / C_{\text {eff }}-1\right)=k q_{0} M / Q-k C_{\text {inf }} V / Q
$$

where $C_{\text {inf }}$ and $C_{\text {eff }}$ are solute concentrations $(\mathrm{mg} / \mathrm{L})$ in the influent and effluent, respectively, $k$ is the Thomas rate constant $(\mathrm{ml} / \mathrm{min} \mathrm{mg}), q_{0}$ is the maximum solid-phase concentration of solute $(\mathrm{mg} / \mathrm{g}), M$ is the mass of adsorbent $(\mathrm{g}), V$ is the throughput volume $(\mathrm{mL})$, and $Q$ is the volumetric flow rate $(\mathrm{mL} / \mathrm{min})$.

As shown in Table 10, the experimental data did not show a good fit to the Thomas model regression equation. Consequently, $q_{0}$ values calculated according to this model should be treated as approximations of the actual values. The amount of metal ion adsorbed per unit weight of pellets decreased in the order $\mathrm{Cu}$ (II) $>\mathrm{Zn}$ (II) $>\mathrm{Cd}$ (II) $>$ $\mathrm{Ni}(\mathrm{II})$. This affinity sequence is almost consistent with that obtained from adsorption isotherm experiments described above, with $\mathrm{Zn}(\mathrm{II})$ and $\mathrm{Cd}(\mathrm{II})$ in reversed positions.

Table 10. Thomas adsorption model parameters for dynamic adsorption of $\mathrm{Cu}(\mathrm{II}), \mathrm{Zn}(\mathrm{II}), \mathrm{Ni}(\mathrm{II})$, and $\mathrm{Cd}(\mathrm{II})$ on pelletized bark at flow rate $5 \mathrm{~mL} / \mathrm{min}$, influent $\mathrm{pH} 5.1 \pm 0.2$, and influent concentration $\approx 10.0 \mathrm{mg} / \mathrm{L}$

\begin{tabular}{|c|c|c|c|c|}
\hline Metal ion & Regression equation & $R^{2}$ & $\begin{array}{c}k, \\
\mathrm{~mL} \mathrm{min-1} \mathrm{mg-1}\end{array}$ & $\begin{array}{c}q_{0}, \\
\mathrm{mg} \mathrm{g}^{-1}\end{array}$ \\
\hline $\mathrm{Cu}(\mathrm{II})$ & $y=-0.0138 x+0.6258$ & 0.7948 & 1.383 & 57 \\
\hline $\mathrm{Zn}(\mathrm{II})$ & $y=-0.0153 x+0.6319$ & 0.8015 & 1.483 & 53 \\
\hline $\mathrm{Ni}(\mathrm{II})$ & $y=-0.0169 x+0.4040$ & 0.7965 & 1.856 & 27 \\
\hline $\mathrm{Cd}(\mathrm{II})$ & $y=-0.0138 x+0.5204$ & 0.7659 & 1.314 & 50 \\
\hline
\end{tabular}

$y=\log \left(C_{\text {inf }} / C_{\text {eff }}-1\right) ; x=V / Q$

\section{Pellet Regeneration and Metal Recovery}

Pellets were regenerated by gentle stirring in $0.5 \mathrm{M} \mathrm{HNO}_{3}$ for $12 \mathrm{~h}$. Figure 4 shows breakthrough curves for six influent concentrations of copper $(1,25,50,70,100$, $250 \mathrm{mg} / \mathrm{L}$ ) passed successively through the column packed with virgin or regenerated pellets. There was practically no difference between the performance of the virgin and regenerated pellets, except at the high influent concentration $(250 \mathrm{mg} / \mathrm{L})$.

It is also important to note that recovery of the metals in dilute nitric acid has the effect of concentrating the metals in solution from which they could be recovered by suitable precipitation or electrochemical methods. The regenerated bark pellets could then be safely used as hog fuel in cogeneration plants.

\section{CONCLUSIONS}

Bark flour from ponderosa pine was consolidated into pellets, using citric acid as cross-linking agent. The pellets were subjected to high-temperature heat treatment. 
1. The pellets did not leach tannins when soaked in water. In the $\mathrm{pH}$ range $2-6$, the pellets showed different capacities for removal of heavy metal ions from synthetic metal ion solutions.

2. The equilibrium amount $q_{\mathrm{e}}$ of $\mathrm{Cu}$ (II) adsorbed per gram of sorbent increased from approximately $0.5 \mathrm{mg}$ at $\mathrm{pH} 6$ to $0.7 \mathrm{mg}$ at $\mathrm{pH}$ 2, and for $\mathrm{Zn}(\mathrm{II})$, from approximately $0.4 \mathrm{mg}$ to $0.7 \mathrm{mg}$.

3. For $\mathrm{Cd}(\mathrm{II})$ and $\mathrm{Ni}(\mathrm{II})$, no $\mathrm{pH}$ effect was apparent on the amounts adsorbed per gram of sorbent, which ranged from approximately 0.4 to $0.5 \mathrm{mg}$ and 0.3 to $0.4 \mathrm{mg}$, respectively.

4. This study demonstrated the potential for converting low-cost bark residues to valueadded sorbents using starting materials and chemicals derived from renewable resources. These sorbents can be applied in the removal of low-concentration toxic heavy metals from waste streams.

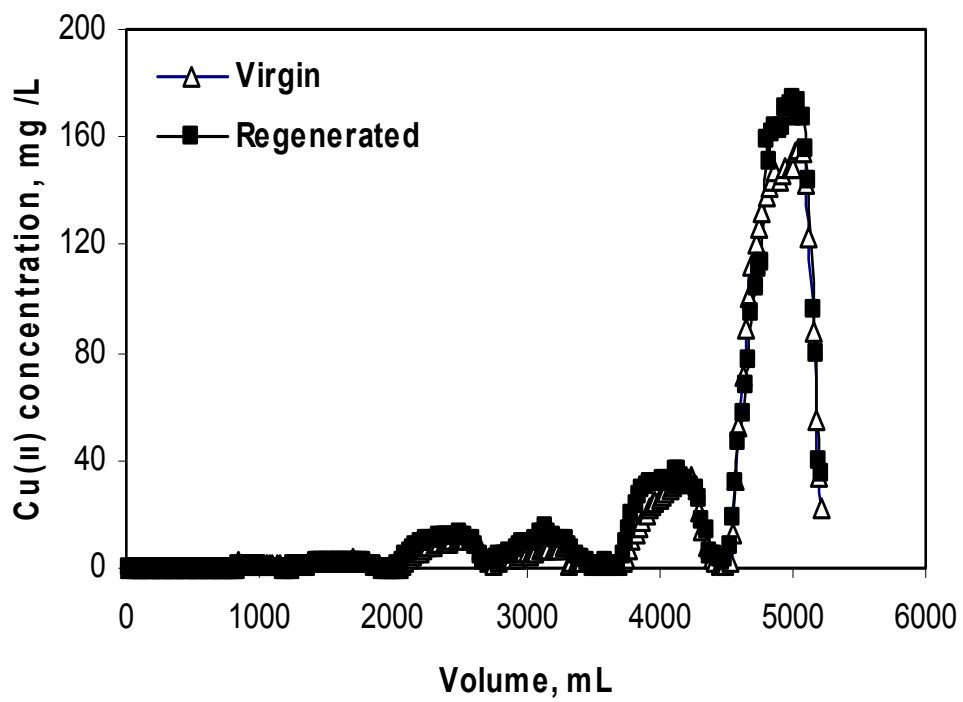

Fig. 4. Breakthrough curves for six influent concentrations $(1,25$, $50,70,100,250 \mathrm{mg} / \mathrm{L})$ of $\mathrm{Cu}(\mathrm{II})$ passed successively through column packed with virgin and regenerated pellets.

\section{ACKNOWLEDGMENTS}

The authors are grateful to the USDA Forest Service, Forest Products Laboratory, for financial support and the opportunity to complete this project. We also thank Dan Foster and Jim Beecher for analytical support, Dan Caulfield for technical advice, Eric O’Neill for technical support, and Steve Verrill for statistical analysis. 


\section{REFERENCES CITED}

Ahmed, S., Chughtai, S., and Keane, M. A. (1998). "The removal of cadmium and lead from aqueous solution by ion exchange with Na-Y zeolite," Separation Purification Technol. 13, 57-64.

Aoyama, M., and Tsuda, M. (2001). "Removal of Cr(VI) from aqueous solutions by bark," Wood Sci. Technol. 35, 425-434.

Bailey, S. E., Olin, T. J., Bricka, R. M., and Adrian, D. D. (1999). "A review of potentially low-cost sorbents for heavy metals," Wat. Res. 33(11), 2469-2479.

Brás, I. P., Santos, L., and Alves, A. (1999). "Organochlorine pesticides removal by Pinus bark sorption," Environ. Sci. Technol. 33(4), 631-634.

Brás, I., Lemos, L. T., Alves, A., Pereira, M., and Fernando, R. (2004). "Application of pine bark as a sorbent for organic pollutants in effluents," Management of Environmental Quality: An International Journal 15(5), 491-501.

Caulfield, D. F., (1994), "Ester crosslinking to improve wet performance of paper using multifunctional carboxylic acids, butanetetracarboxylic and citric acid," Tappi Journal, 77(3), 205-212.

Deshkar, A. M., Bokade, S. S., and Dara, S. S. (1990). "Modified Hardwickia binata bark for adsorption of mercury (II) from water," Water Res. 24(8), 1011-1016.

DesMarais, T. A., Stone, K. J., Thompson, H. A., Young, G. A., LaVon, G. D., and Dyer, J. C. (1993). "Absorbent foam materials for aqueous body fluids and absorbent articles containing such materials," United States Patent 5,268,224.

Fatoki, O. S., and Mathabatha, S., (2001), "Assessment of heavy metal pollution in the East London and Port Elizabeth harbours," Water SA, 27(2), 233-240.

Frigon, J. C., Cimpola, R., and Guiot, S. R. (2003). "Sequential anaerobic/aerobic biotreatment of bark leachate," Water Sci. Technol. 48(6), 203-209.

Gaballah, I., and Kilbertus, G. (1998). "Recovery of heavy metal ions through decontamination of synthetic solutions and industrial effluents using barks," $J$. Geochemical Exploration 62, 241-286.

Haussard, M., Gaballah, I., Kanari, N., De Donato, Ph., Barrès, O., and Villieras, F. (2003). "Separation of hydrocarbons and lipid from water using treated bark," Water Res. 37, 362-374.

Ho, Y. S., and McKay, G. (1999). "Pseudo-second order model for sorption processes," Process Biochem. 34, 451-465.

Huheey, J. E. (1972). Inorganic Chemistry: Principles of Structure and Reactivity, Harper \& Row, New York.

Ji, J., and Cooper, W. C. (1996). "Nickel speciation in aqueous chloride solutions," Electrochimica Acta 41(9), 1549-1560.

Kapoor, A., and Viraraghavan, T. (1998). "Removal of heavy metals from aqueous solutions using immobilized fungal biomass in continuous mode," Water Res. 32(6), 1968-1977.

Kulicke, W-M., Kull, A. H., Kull, W., and Thielking, H., (1996)“Characterization of aqueous carboxymethylcellulose solutions in terms of their molecular structure and its influence on Rheological behaviour," Polymer, 37(13), 2723-2731. 
Leyva-Ramos, R., Rangel-Mendez, J. R., Mendoza-Barron, J., Fuentoes-Rubio, L., and Guerrero-Coronado, R. M. (1997). "Adsorption of cadmium(II) from aqueous solution onto activated carbon," Water Sci. Technol. 35(7), 205-211.

Martin-Dupont, F., Gloaguen, V., Granet, R., Guilloton, M., Morvan, H., and Krausz, P. (2002). "Heavy metal adsorption by crude coniferous barks: a modeling study," $J$. Environ. Sci. Health Part A 37(6), 1063-1073.

Martin-Dupont, F., Gloaguen, V., Guilloton, M., Granet, R., and Krausz, P. (2004). "Chemical modifications of Douglas Fir bark, a lignocellulosic by-productenhancement of their lead(II) binding capacities," Separation Sci. Technol. 39(7), 1595-1610.

Martin-Dupont, F., Gloaguen, V., Guilloton, M., Granet, R., and Krausz, P. (2006). "Study of the chemical interaction between barks and heavy metal cations in the sorption process," J. Environ. Sci. Health Part A 41, 149-160.

McKeever, D. B., and Falk, R. H. (2004). "Woody residues and solid waste wood available for recovery in the United States, 2002," Management of Recovered Wood Recycling, Bioenergy and Other Options, European COST E31 Conference Proceedings, C. Gallis, (ed.).

Morais, L. C., Freitas, O. M., Gonçalves, E. P., Vasconcelos, L. T., and González, B. C. G. (1999). "Reactive dyes removal from wastewaters by adsorption on Eucalyptus bark: variables that define the process," Water Res. 33(4), 979-988.

Namasivayam, C., and Yamuna, R. T. (1992). "Removal of Congo red from aqueous solutions biogas waste slurry," J. Chem. Technol. Biotechn. 53, 153-157.

Raji, C., and Anirudhan, S. (1998). "Batch Cr(VI) removal by polyacrylamide-grafted sawdust: kinetics and thermodynamics," Water Res. 32(12), 3772-3780.

Randall, J.M. (1977). "Variation in effectiveness of barks as scavengers for heavy metal ions," Forest Products J. 27(11), 51-56.

Ratola, N., Botelho, C., and Alves, A. (2003). "The use of pine bark as a natural adsorbent for persistent organic pollutants - study of lindane and heptachlor adsorption," J. Chem. Technol. Biotechn. 78, 347-351.

Reddy, B. R., Mirghaffari, N., and Gaballah I. (1997). "Removal and recycling of copper from aqueous solutions using treated Indian barks," Resources Conservation Recycling 21, 227-245.

Sakai, K., (2001) "Chemistry of Bark" in Wood and Cellulosic Chemistry, Edited by David N.-S. Hon, Nobuo Shirashi, Marcel Dekker, Inc., New York, Chapter 7, 243273.

Sekar, K. C., Kamala, C. T., Chary, N. S., Sastry, A. R. K., Rao, T. N., and Vairamani, M. (2004). "Removal of lead from aqueous solutions using immobilized biomaterial derived from a plant biomass," J. Hazardous Materials B108, 111-117.

Seki, K., Saito, N., and Aoyama, M. (1997). "Removal of heavy metal ions from solutions by coniferous barks," Wood Sci. Technol. 31, 441-447.

USEPA Method 6010B (1996). "Inductively coupled plasma-atomic emission spectrometry," CD-ROM, Revision 2, 1-25

Van Hassel, J. H., Ney, J. J., and Garling, Jr., D. L., (1980) "Heavy metals in a stream ecosystem at sites near highways," Transactions of the American Fisheries Society, 109, 636-643. 
Vázquez, G., González-Álvarez, J., Freire, S., López-Lorenzo, M., and Antorrena, G. (2002). "Removal of cadmium and mercury ions from aqueous solution by sorption on treated Pinus pinaster bark: kinetics and isotherms," Bioresource Technol. 82, 247-251.

Villaescusa, I., Martinez, M., and Miralles, N. (2000). "Heavy metal uptake from aqueous solution by cork and yohimbe bark wastes," J. Chem. Technol. Biotechn. 57, 812-816.

Vuceta, J., and Morgan, J. J. (1977). “Hydrolysis of Cu(II),” Limnol. Oceanog. 22(4), $742-746$.

Zhang, Y., and Muhammed, M. (2001). "Critical evaluation of thermodynamics of complex formation of metal ions in aqueous solutions - VI. Hydrolysis and hydroxocomplexes of $\mathrm{Zn}^{2+}$ at 298.15 K," Hydrometallurgy 60, 215-236.

Article submitted: Dec. 21, 2006; First round reviewing completed: Feb. 5, 2007; Revised version accepted: Feb. 15, 2007; Published Feb. 17, 2007 